\title{
Jurisdiction, Privacy, and Ownership: DNA Technology and Field Dynamics in Conflict-Related Mass Fatalities
}

\author{
Stefan Schmitt \\ Dallas Mazoori \\ Independent Researcher
}

Follow this and additional works at: https://digitalcommons.usf.edu/gsp

\section{Recommended Citation}

Schmitt, Stefan and Mazoori, Dallas (2017) "Jurisdiction, Privacy, and Ownership: DNA Technology and Field Dynamics in Conflict-Related Mass Fatalities," Genocide Studies and Prevention: An International Journal: Vol. 11: Iss. 1: 55-81.

DOI:

http://doi.org/10.5038/1911-9933.11.1.1452

Available at: https://digitalcommons.usf.edu/gsp/vol11/iss1/8

This Symposium on the State of the Field is brought to you for free and open access by the Open Access Journals at Digital Commons @ University of South Florida. It has been accepted for inclusion in Genocide Studies and Prevention: An International Journal by an authorized editor of Digital Commons @ University of South Florida. For more information, please contact digitalcommons@usf.edu. 


\section{Introduction}

Criminal investigations and trials center around identifying evidence relevant to a defined crime and linked to an identified perpetrator and identifiable victim. In the case of death investigations, the cause of death is determined by a government authority - a medical examiner or coronerto be homicide, suicide, accidental, natural or undetermined. This determination has defined legal consequences, such as the opening of a criminal investigation in the case of a homicide. Part of the state's responsibility in the course of a death investigation is to ensure that the victim is correctly identified as the individual they were at birth. It is therefore in the state's interest to ensure that human identifications are conducted under controlled circumstances and are subject to judicial review. The state acknowledges the death, generally via a death certificate, and ensures the implementation of legal consequences and processes, and in the course of so doing, effectively acknowledges the truth of what happened.

In the thirty years since DNA profiling was first used in a criminal case, ${ }^{1}$ investigators have come to rely on DNA as an important tool in identifying individuals, whether living or deceased. The role of DNA-supported identifications of human remains in mass fatalities has become particularly important as a means of dealing with large numbers of unidentified victims. In countries experiencing armed conflict or emerging therefrom, rule of law and with it forensic services are at best overwhelmed or have ceased functioning altogether. The short term solution of outsourcing human identifications with the intent of expediting the identification and repatriation of remains to the families of victims is one that appeals to national decision makers, victim families, and often also the international donor community. This can, however, lead to neglect of existing national forensic and infrastructure and the state's obligation of due process in the case of wrongful deaths, divorcing the local jurisdiction from the overall human identification effort. ${ }^{2}$

The current article explores the dynamics and challenges of undertaking human identifications in states experiencing armed conflict or emerging therefrom. Of primary concern to the authors is the fact that where a state lacking the necessary forensic infrastructure outsources DNA work for human identifications, it tends to lead to the abdication of the necessary jurisdiction and scientific transparency over DNA samples and their analysis. This can complicate the resolution of discrepancies that may arise between DNA laboratory results and field investigations. It also raises important questions about consent, privacy and human rights. The authors argue that the role of the State remains integral to a legitimate human identification process. It is the State that makes the ultimate decision to identify an individual and confirm their death, and it is the State that is responsible for human rights, the right to the truth, civil identity and, through its administrative and judicial organs, review of decisions-something that can be overlooked in an outsourced context. Attempting to minimize initial delays in human identifications at the expense of building local knowledge, skills and necessary legal frameworks risks undermining the legitimacy of the human identification effort.

\section{Human Identifications}

Positive Human Identifications

Positive identification is a term used in the context of forensic human identifications to refer to the definitive determination that a person or deceased remains is that of a specified individual. ${ }^{3}$

\footnotetext{
${ }^{1}$ See $R v$ Pitchfork, England and Wales Court of Appeal, May 14, 2009.

${ }^{2}$ Stefan Schmitt, Amanda Sozer, Gillian Fowler and Dallas Mazoori, "Physicians for Human Rights: The Role of Forensic Archaeology in Transitional Justice Contexts," in Forensic Archaeology: A Global Perspective, ed. W.J. Mike Groen et al. (Chichester: Wiley-Blackwell, 2015), 476.

${ }^{3}$ Segen's Medical Dictionary, "Positive Identification," accessed August 5, 2016, http://medical-dictionary. thefreedictionary.com/positive+identification.
}

Stefan Schmitt and Dallas Mazoori, "Jurisdiction, Privacy, and Ownership: Dna Technology and Field Dynamics in Conflict-Related Mass Fatalities" Genocide Studies and Prevention 11, 1 (2017): 55-81. @2017 Genocide Studies and Prevention. 
A positive identification involves correlating known information about the deceased (or a missing person) with information from the body to a level of certainty so that a legal authority, typically medical examiner or coroner, is satisfied that the deceased individual is who they are recorded to be within an identification system, such as a civil registry.

\section{Positive Human Identifications in Mass Fatalities}

A mass fatality is an event resulting in more deaths than the local available resources can process. ${ }^{4}$ A mass fatality event can be manmade (armed conflict), natural disaster (tsunami), or accident that may be due to manmade or natural causes (plane crash). Mass fatalities occur under chaotic and uncontrolled conditions, and the number of victims is outside of what established forensic, law enforcement and judicial entities are prepared to handle. Such a context also requires stringent controls over the identification of human remains, which can often be fragmented, commingled, and it is unknown who exactly the victims could be.

Interpol has addressed this for controls in their Disaster Victim Identification Guide. ${ }^{5}$ Interpol divides identification criteria into primary and secondary means of identification. The primary and most reliable means of identification are fingerprint comparisons between those of the decedent with existing fingerprint records, comparative dental analysis between existing dental records and the dental traits of the deceased and DNA kinship relationship and/or match analysis. Secondary means of identification include personal description, medical findings as well as evidence and clothing found on the body. Secondary means of identification serve to support identification by primary means and are not sufficient as a sole means of identification in mass fatalities. However, even where a strong primary identification standard has been achieved it is good practice to record other evidence that supports the identification.

Unlike identifications that are made within the routine operations of a medical examiner, where often times the deceased is identified without primary means of identification (fingerprint, dental records, DNA) as the visual identification of the body by next of kin supported by the circumstances in which the death occurred are considered sufficient, ${ }^{6}$ identification in mass fatalities where the context is not controlled should never be made solely by means of visual recognition.

The identification of human remains is therefore necessarily forensic in that the identification is a legal determination (sealed by the jurisdictional authority's signature on a death certificate) based on the scientific matching of information on reported missing persons with unidentified human remains. ${ }^{7}$ The ways and methods through which this information is obtained and matched are important. The use of incorrect methods for collecting and documenting findings may render data, and the conclusions drawn from it, legally unacceptable, thus negatively impacting identification efforts. ${ }^{8}$ For this reason, transparency in the processes and decision-making involved in them, coupled with the availability of review, is essential.

\section{Dynamics of Human Identification Efforts in Mass Fatality Situations}

The complexity of a human identification effort in the mass fatality context reflects the complexity of the event itself, and requires different agencies and jurisdictions to work together. ${ }^{9}$ The knowledge, approaches, procedures and functions of the range of actors involved in mass fatality response can vary significantly. A proper chain of command and organisational structure is essential to ensuring effective coordination between the different actors and elements. ${ }^{10}$ In addition, every mass fatality

\footnotetext{
${ }^{4}$ Amanda Sozer, DNA Analysis for Missing Person Identification in Mass Fatalities (Boca Raton: CRC Press, 2014), 23.

${ }^{5}$ Interpol, Disaster Victim Identification Guide (Interpol, 2014), 39-40 and Annexure 12 "Methods of identification," 94-97, accessed May 10, 2017, https://www.interpol.int/INTERPOL-expertise/Forensics/DVI-Pages/DVI-guide.

${ }^{6}$ David Dolinak and Evan Matshes, "Identification," in Forensic Pathology: Principles and Practice, ed. David Dolinak et al. (Burlington: Elsevier, 2005), 555-562.

${ }^{7}$ International Committee of the Red Cross, Missing People, DNA Analysis and Identification of Human Remains: A guide to best practice in armed conflicts and other situations of armed violence, 2nd ed. (Geneva: ICRC, 2009).

${ }^{8}$ Amanda Sozer, DNA Analysis, 31.

${ }^{9}$ Ibid., 23.

${ }^{10}$ See Disaster Victim Identification Guide, 9, 34.
} 
response should be subject to the laws and rules of the country in which it occurs, to ensure that the response is situated within a legal framework that is legally and constitutionally supported in that jurisdiction. ${ }^{11}$

It is important to recognise the following dynamics in mass fatality human identifications: ${ }^{12}$

- The human identification effort in response to the mass fatality is temporary in nature. Ultimately, the objective is to repatriate the remains of the dead to their families and determine the truth about what happened. Such a process might take decades.

- The resources needed to adequately respond to a mass fatality exceed existing forensic, law enforcement, and judicial capacities and will require temporary additional resources.

- Identifications and repatriation of remains will take time and some remains might never be identified or returned to their families.

- Expectations and consent of families regarding the use of DNA samples and the duration of the project need to be managed and addressed from the onset.

- It is important to decide on criteria for when the identification effort is concluded. ${ }^{13}$ Eventually the project will wind down and the remaining workload should be integrated into routine governmental operations.

- A human identification effort needs to address the rights of victims' families to know the truth about what happened to their loved ones.

- The identification of human remains is a judicial decision based on forensic science to identify a particular set of human remains as the person they were identified as at birth. In many cases this will be by the state itself via a death certificate.

As mentioned, all human identifications are necessarily forensic in that the identification of human remains is an act of the state based on scientific inquiry. This scientific inquiry is the statutory duty of the medical examiner or coroner in most countries and should be the same in every death investigation so that each victim, whether one or 1000, is accorded the same consideration under the laws governing the investigation of and response to sudden or violent death. ${ }^{14}$

Sometimes, overwhelmed resources necessitate altering the response. For example, following the 9/11 attacks on the World Trade Center in New York City, the Chief Medical Examiner decided that given the cause and manner (blunt force trauma, homicide) were not in question, the primary focus was not on establishing the cause of death but on providing positive identification of the human remains, issuing death certificates and repatriating the remains to the victims' families. ${ }^{15}$

A mass fatality overwhelms the resources that routinely are at the disposition of any medical examiner. As DNA has become an efficient tool in processing large numbers of samples for the purposes of identification, the outsourcing of DNA profiling work to private laboratories is often a temporary solution. In such cases though, it still is the medical examiner in their forensic role who ultimately decides whether an identification can be made based on the data generated by the contracted laboratory. In that sense, jurisdiction over the samples, as well as any data resulting from the testing (the genetic profile) and its analysis, should be considered the responsibility of the medical examiner in the local jurisdiction. ${ }^{16}$ In contexts where sample testing and analysis

\footnotetext{
${ }^{11}$ Ibid., 19.

${ }^{12}$ Stefan Schmitt, Amanda Sozer, William Haglund, Nizam Peerwani, Howard Varney and Robert Lamburne, Libyan Human Identification Needs Assessment and Gap Analysis (Cambridge, MA: Physicians for Human Rights, 2013$), 11$.

${ }^{13}$ National Institute of Justice, Lessons Learned From 9/11: DNA Identification in Mass Fatality Incidents, (Washington, DC: National Institute of Justice, 2006).

${ }^{14}$ National Institute of Justice, Mass Fatality Incidents: A Guide for Human Forensic Identification (Washington, DC: National Institute of Justice, 2005), v.

${ }^{15}$ Gaille MacKinnon and Amy Z. Mundorff, “The World Trade Center-September 11, 2001," in Forensic Human Identification: An Introduction, ed. Timothy James Upton Thompson and Sue M. Black, (Boca Raton: CRC Press, 2007), 487-488.

${ }^{16}$ Disaster Victim Identification Guide, "Jurisdiction."
} 
is outsourced, it is also recommended to retain duplicate samples to allow for duplicate testing and/or analysis by a third party. ${ }^{17}$ Such practice can be an important quality control measure and is particularly important where discrepancies or other doubts about the results given by the outsourced laboratory need to be independently reviewed. ${ }^{18}$

The management of the identification process from DNA sample collection to the extraction of profiles in the laboratory, the matching of such profiles, to the final issuing of identifications and death certificates can be difficult to achieve in contexts where states simply do not have the forensic infrastructure, capacity or an adequate medico-legal framework within which such a human identification effort is to be situated. Any mass fatality human identification effort needs to be viewed in its local social, political, cultural and economic context with due consideration given to whether a human identification effort is even possible, let alone sustainable. ${ }^{19}$

In recognition of such challenges on an international level, Interpol recommends the formation of an Identification Board that makes final decisions regarding the identification of victims. The composition of this Board is dependant on existing legal frameworks and its final jurisdiction is to be the home country for the victim identification, such as a coroner, judge, medical examiner, military or police authority..$^{20}$

Often a mass fatality situation is understood as one requiring an immediate humanitarian response to grieving families resulting in the marginalisation of the legal aspects of the identification of human remains. ${ }^{21}$ The following principles should be standard as part of any mass fatality human identification effort: ${ }^{22}$

- Victims have a right to their identity after their death;

- All victims are treated equally in the identification process - there is no discrimination on any basis whatsoever; ${ }^{23}$

- Victims are identified on the basis of set standards; and

- A single error can seriously damage the integrity of the entire process and any future processes.

How DNA Changed the Human Identification Landscape

Prior to the inclusion of DNA profiling as a tool in what for the purposes of this paper has been defined as primary means of identification, identifications relied on one to one body landmark comparisons. ${ }^{24}$ Those established as most reliable are comparison of existing dental, medical, or fingerprint records with the corresponding body landmarks of the deceased. This requires the existence of such records, which often do not exist in countries experiencing or emerging from armed conflict. The deceased may have never visited a doctor or a dentist, or if they have, records may have been destroyed or never kept. Fingerprint records are generally only available if the deceased has been fingerprinted previously. ${ }^{25}$ Medical records need to include documentation unique enough to establish a level of certainty in the positive identification that this could only be the deceased and none other. Even where records exist, they may be of little to no use in

\footnotetext{
${ }^{17}$ Lessons Learned From 9/11, 75.

${ }^{18}$ Amanda Sozer, et al, Guidelines for Mass Fatality DNA Identification Operations (Bethesda: AABB, 2010).

${ }^{19}$ Stefan Schmitt, Amanda Sozer and Dallas Mazoori, Securing Afghanistan's Past: Human Identification Needs Assessment and Gap Analysis (Cambridge, MA: Physicians for Human Rights, 2013), 6.

${ }^{20}$ Disaster Victim Identification Guide, 81.

${ }^{21}$ Schmitt et al, Securing Afghanistan's Past, 8.

${ }^{22}$ Disaster Victim Identification Guide, 39.

${ }^{23}$ Discrimination of victims on the basis of political (e.g. martyrs vs. missing) or other reasons is likely to introduce a sampling bias in reporting missing persons and consequently decrease the success rate at which identifications of human remains are made. See Schmitt et al, Libyan Human Identification, 19.

${ }^{24}$ Bruce Budowle, Frederick R. Bieber and Arthur J. Eisenberg, “Forensic aspects of mass disasters: Strategic considerations for DNA-based human identification," Legal Medicine 7 (2005), 231.

${ }^{25}$ For example, fingerprint identifications were successfully undertaken in Thailand following the December 2004 Tsunami as Thai citizens are routinely fingerprinted when they obtain their national ID card.
} 
circumstances in which remains are highly fragmented or degraded and for which such body landmark comparisons are impossible.

Why DNA is a Game Changer

DNA-based testing is a powerful tool for victim identification as data is not restricted to any particular body landmark comparison, nor does it require existing records (such as fingerprints, medical or dental records) for comparison purposes. ${ }^{26} \mathrm{DNA}$ can be extracted from almost any tissue of the body of a deceased victim and can be compared to either pre-existing samples of a deceased's $\mathrm{DNA}^{27}$ or in comparison with DNA from next of kin. DNA can be extracted from minute biological samples, diminishing the importance of the existence of a full mouth of teeth or the preservation of skin with sufficient ridge detail on the fingers in the remains of a deceased. Furthermore, whereas identifications based on one-to-one body landmark comparisons couldn't generate a statistical level of certainty in an identification, DNA for the first time was able to generate statistics which quantified the level of certainty of an identification. DNA technology made positive identifications possible without the need for a preserved body with its unique individual features.

DNA analysis effectively became the main tool for human identifications in mass fatality incidents. Consequently, the role of the DNA laboratory and its requirements for consistent sample collection and processing needed to be integrated into what traditionally had been the responsibility of death investigators in their efforts to locate and collect secondary means of identification as well as existing medical, dental, and/or fingerprint records for comparison purposes.

Prior to the advent of DNA analysis in the international arena of mass fatalities resulting from conflict, the medical examiner and/or forensic anthropologists and archaeologists (in the case of mass grave exhumations) controlled the entire process from exhumation in the field to the postmortem analysis of the remains in the laboratory. Due to the need for strict quality control and assurance processes in a DNA laboratory, ${ }^{28}$ it became necessary to control consistency of biological sample collection in the field to their submission to the DNA laboratory. This needed to be linked with witness testimony (antemortem information) and postmortem analysis that established the biological profile of the unidentified human remains for purposes of narrowing down candidates for identification prior to engaging in costly DNA analysis. From an administrative and managerial aspect, the DNA laboratory came to dominate many aspects of the identification effort-from antemortem data/witness testimony gathering to exhumations and sample collection. DNA samples needed to be collected not only from the remains, but also from next of kin, and their relationship with the suspected missing person established. Effectively, anything collected in the field pertinent to DNA collection and analysis needed to be entered into the laboratory information management system and consequently had to comply with the laboratory's quality assurance and control processes to ensure reliable results which includes chain of custody level handling of samples and data. ${ }^{29}$

The efficiency with which DNA profile matching and analysis in mass fatalities can now be done has established it in many ways as the primary method of identification with traditional methods, such as fingerprints and dental records, verified by DNA analysis. Secondary means of identification, such as witness descriptions of the victim, general medical conditions during life, and circumstances of disappearance or death of the victim, are used in support of the DNA profile match. ${ }^{30}$ These means of identification equally have to be coordinated with the DNA laboratory and the management of that data has to be integrated into the DNA led identification effort.

\footnotetext{
${ }^{26}$ Lessons Learned From 9/11, 13.

${ }^{27}$ Reference samples can be collected from known personal items such as toothbrushes, hair brushes, razors, and others. See Lessons Learned From 9/11, 5.

${ }^{28}$ Sozer, et al, Guidelines for Mass Fatality DNA Identification Operations.

${ }^{29}$ Ibid.

${ }^{30}$ For example, inconsistencies between information from secondary means of identification with profile matches in the laboratory can be indications of errors that might have occurred in the sample collection process, i.e. sample switches, or in the data collection effort, which need to be resolved.
} 


\section{Relevance of Civil Identity to DNA Identifications}

Right to an Identity under International Law

The provisions of international human rights treaties centered around birth registration and acquisition of nationality ${ }^{31}$ require states to grant each person a name and legal personality, typically by issuing identity documents that are linked to rights and responsibilities within the state. The issuing of a birth certificate grants certain rights and responsibilities, and is often instrumental to the exercise of a myriad of other rights including the right to education, the right to work, the right to the highest attainable standard of health and the right to recognition as a person before the law. It is also allows the State to assert its rights in respect of the citizen. Similarly, the issuing of a death certificate has important legal implications for surviving family members, including in areas such as inheritance, land title, custody of children and compensation and insurance. Equally importantly though, it is also the process through which the cause and manner of death is certified. The ruling of a death to be the result of a homicide places the legal responsibility to investigate and adjudicate the death on the state. The issuance of a death certificate is not just a judicial determination identifying a person as he or she was identified at birth - civil identity - but also an important part of maintaining the rule of law by determining the cause and manner of death and investigating suspicious deaths. ${ }^{32}$

\section{The Importance of Civil Identity in Mass Fatality Human Identification Efforts}

The process of generating one's civil identity is performed through forensic human identification. For forensic purposes, an identity in such a case can be based on various factors, ranging from documentary evidence (adoption papers), to fingerprints, to DNA (affiliation with biological parents). In some cases, a subjective identification based on recognition of the remains in a controlled environment by witnesses and circumstantial evidence (e.g., someone died in bed surrounded by family members) is confirmed judicially by the medical examiner. The exact method of forensic human identification depends on the circumstances surrounding the death and the available evidence. In armed conflicts where people have died in uncontrolled circumstances and their remains have been lost, DNA identification plays an important role in establishing an individual's identity. However, DNA is only one piece of evidence in the human identification process and needs to be evaluated along with all other evidence. ${ }^{33}$

Civil identity takes on additional importance in mass fatality incidents, such as armed conflict. The humanitarian response to such incidents often overlooks the need for human identifications to be carried out within their proper legal context, according to standard forensic practices. Often death certificates are needed before inheritance and property transfers can proceed or before orphaned children can be placed in the care of guardians. In such contexts, an integrated system of civil identity that includes birth, death and marriage certificates play an important role in not only the human identification process, but also in the restoration of rights post-mass fatality.

\section{The Need for a Domestic Legal Framework in Human Identifications Jurisdiction}

In any mass fatality human identification or disaster response effort the establishment of a clear command and control structure headed by a local authority that operates in accordance with the local legal framework is essential. Foreign experts and law enforcement officers deployed as part of a response need to be mindful that in general they have no legal powers within the host country and remain guests of that country. ${ }^{34}$

\footnotetext{
${ }^{31}$ United Nations, Universal Declaration of Human Rights, Art 15(1), G.A. Res. 217A (III), UN GAOR, 3rd session, 183rd plen mtg., UN Doc A/810, 10 December 1948; International Covenant on Civil and Political Rights, Arts. 24(2), (3), opened for signature 19 December 1966, 999 U.N.T.S. 171, entered into force 23 March 1976; Convention on the Rights of the Child, Arts. 7, 8, opened for signature 20 November 1989, 1577 U.N.T.S. 3, entered into force 2 September 1990.

${ }^{32}$ Schmitt et al, Libyan Human Identification, 11-12; Schmitt et al, Securing Afghanistan's Past, 9-10.

${ }^{33}$ Ibid.

${ }^{34}$ Interpol, Interpol Tsunami Evaluation Working Group: The DVI Response to the South East Asian Tsunami between December 2004
} 
As science has advanced, the forensic expert witness has come to be an integral actor in the criminal trial. Regardless of the circumstances in which a forensic expert testifies, they must do so honestly, impartially and independently, and be able to attest to such independence as part of any prepared report. ${ }^{35}$ The domestic legal framework of the local jurisdiction provides not only the means by which the legitimacy of the scientific data, collection and analysis can be examined and reviewed, but also the means by which forensic experts are certified as competent to provide expert opinion evidence. Supervisory regulation allows for independent bodies to regularly check systems and evidence in individual cases. ${ }^{36}$ This type of mandated transparency is essential in establishing public credibility in the results obtained by forensic scientists. ${ }^{37}$

\section{Cross-examination and Review}

Within a domestic legal framework, forensic evidence, like other forms of evidence, can-and should - be tested. In the adversarial trial evidence is tested in accordance with established rules of evidence and criminal procedure. The defence can cross-examine the prosecution's forensic expert and, in most jurisdictions, can also call an independent forensic expert to advance an alternative case theory or create reasonable doubt in the evidence proffered by the prosecution.

Access to judicial review of DNA laboratories, their scientists, and records is particularly important when it comes to the resolution of discrepancies that arise in human identifications. This is particularly salient when DNA matches done in the laboratory between reference samples (from the unidentified remains) and alleged family members are contradicted by the data gathered in the field. Discrepancies such as this indicate a problem somewhere between the sample and antemortem data collection and the sample processing and DNA matching done in the DNA laboratory. This can include things such as quality control issues in laboratories or at any step prior, accidental sample switches or mix-ups, contamination of samples or equipment, or miscommunication between field investigators and sample collectors. In a forensic setting these type of quality control issues are resolved by transparent technical, scientific and administrative responses, such as laboratory accreditations. This transparency is necessary to ensure confidence both in the science and technology behind the employed forensic science, and in the administration of justice as a whole.

In most western democracies, forensic DNA laboratories are accountable to the judiciary and are often state institutions precisely for this reason. In cases where transparency, methods or findings are questioned by the public, defendants, or even the prosecutor, most legal systems allow for the review of evidence by independent experts. These experts are brought into the judicial process and granted access to evidence and reports, either for review processes or for reexaminations/-testing of evidence and/or samples.

The need for independent review of scientific techniques involved in DNA profiling was highlighted early on in the development of DNA evidence by the decision of the New York State Supreme Court in People $v$ Castro. ${ }^{38}$ The defendant was charged with two counts of murder in the second degree in respect of a pregnant 21 year old woman and her two-year-old daughter. The prosecution intended to prove at trial that a bloodstain on the defendant's wristwatch was the blood of the murdered woman. Judge Sheindlin found that the Lifecodes testing laboratory failed in its responsibility to perform the accepted scientific techniques and experiments capable of producing reliable results in DNA identification. ${ }^{39}$ As a result, key DNA evidence was ruled inadmissible.

Although Castro ended up pleading guilty, the ruling on admissibility had a significant impact upon the use of DNA evidence in criminal proceedings, not just in the United States but around the world. It showed, for the first time, that DNA evidence was not infallible. It led to

and February 2006 (Interpol, 2010), 48.

${ }^{35}$ Roy Beran, “The Role of the Expert Witness in the Adversarial Legal System," Journal of Law and Medicine 17, no. 1 (2009), 135.

${ }^{36}$ Michael Kirby, "Forensic Evidence: Instrument of Truth or Potential for Miscarriage?," Journal of Law, Information and Science 20, no. 1 (2010), 1.

${ }^{37}$ Schmitt et al, Physicians for human rights, 472.

${ }^{38}$ People v Castro, New York Supreme Court, August 14, 1989.

${ }^{39}$ For further discussion of the Castro case see, for example, Ian Freckelton, "DNA Profiling: Forensic Science under the Microscope," Criminal Law Journal 14, no. 1 (1990), 35. 
the establishment, by Castro's defence lawyers, of the Innocence Project-an organisation that exonerates the wrongly convicted through DNA testing and reforms the criminal justice system to prevent future injustices.$^{40}$ At the time of writing, the Innocence Project has seen 349 people in the United States exonerated by DNA testing-including 20 who served time on death row-and 149 real perpetrators found. ${ }^{41}$ The Castro case shows how an adversarial system in which equal access to highly qualified experts is afforded is especially well-suited for revealing limitations and weaknesses in evidence that other evaluative methods, including scientific peer review, reputation and publication, may not necessarily uncover. ${ }^{42}$ One of the reasons for this is the power of courts to compel disclosure of what would otherwise be confidential information. ${ }^{43}$

Many states experiencing or emerging from armed conflict are lacking in forensic capacity and infrastructure. If a human identification effort is to go ahead it may be necessary to outsource by removing samples and/or evidence from the national jurisdiction for testing and analysis. Whilst this may result in identifications being made when they otherwise would not have been possible, it separates the DNA analysis from a local context in which it can be verified or challenged. Discrepancies between crime scene and lab can be difficult to reconcile where communication between the lab and the field, and especially surviving victims, is challenging at best.

States experiencing or emerging from armed conflict may also lack an adequate legal framework and a legal culture that is conducive to independent review. There may not be a culture of robust criminal defence or a legal aid system. Defence counsel may be hampered by an inability to review substandard crime scene processes and documentation or to request access to physical evidence. There may not be a pool of independent forensic experts or a culture of independent expert opinion in the legal system. Corruption may be significant. There may be no ability to protect witnesses or witness and victim privacy, something that raises additional concerns where DNA evidence is involved.

\section{The Right to Privacy}

DNA is more than just a powerful piece of evidence admitted in the criminal trial. The personal information that can be obtained from DNA "has no parallel in the history of science and raises profound questions about the protection of privacy." ${ }^{44}$ Unlike fingerprints, DNA can reveal information about an individual and their family that goes beyond profile matching for purposes of identification. This can range from discovering personal family relationships (e.g. that unbeknownst to a father, a particular individual isn't their biological child to determining ancestry (the genetic affiliation with a particular group or population) to predispositions to particular diseases. ${ }^{45}$ Any of this information can be used to the detriment of the individual donating their biological sample for the purposes of DNA analysis.

The concern over genetic privacy with respect to the biological sample is therefore one as to what type of DNA testing is done, what kind of analysis is performed, and what is done with the biological sample after the analysis has been completed. An important aspect of DNA profiles/ fingerprints used in human identification efforts is that they are limited to a small section of DNA, which has been proven to be unique between individuals. Other than tracking family relations, it really can't be used for much else. A biological sample can be used to extract an individual's entire genome, containing the entire set of their genetic information, but this is an entirely different

\footnotetext{
${ }^{40}$ Innocence Promect, 2016, accessed March 21, 2017, www.innocenceproject.org.

${ }^{41}$ Ibid.

${ }^{42}$ Jennifer L. Mnookin, "People v Castro: Challenging the Forensic Use of DNA Evidence," Journal of Scholarly Perspectives 3 , no. 1 (2007), 78.

${ }^{43}$ Ibid., 94.

${ }^{44}$ Robin Williams and Paul Johnson, "Inclusiveness, effectiveness and intrusiveness: Issues in the developing uses of DNA profiling in support of criminal investigations," Journal of Law, Medicine and Ethics 33, no. 3 (2005), 551, citing a submission by Liberty in the Marper case. See also "Intervention by Liberty," December 14, 2007, accessed May 10, 2017, https://www.liberty-human-rights.org.uk/sites/default/files/s-and-marper-v-uk-european-court-of-human-rights-2007.pdf.

${ }^{45}$ Khaleda Parven, "Forensic Use of DNA Information v Human Rights and Privacy Challenges," University of Western Sydney Law Review 17 (2013), 45-46.
} 
process. Hence, the need to outline the exact purpose of collecting biological profiles and their disposition, what type of DNA analysis is done and how long the biological sample remains stored.

In the case of $S$ and Marper $v$ United Kingdom ${ }^{46}$ the European Court of Human Rights found that the indiscriminate and indefinite retention of fingerprints, cellular samples and DNA profiles of individuals who were suspected, but not convicted, of offences was a breach of the applicants' right to respect for their private lives within the meaning of Article 8 of the European Convention on Human Rights. The Court held that given the nature and amount of personal information contained in cellular samples, their retention per se must be regarded as interfering with the right to respect for the private lives of the individuals concerned. ${ }^{47}$ That only a limited part of this information is actually extracted or used by the authorities through DNA profiling and that no immediate detriment is caused in a particular case does not change this conclusion. ${ }^{4}$ The Court observed that DNA profiles - whilst in coded form, intelligible only with the use of computer technology and capable of being interpreted only by a limited number of persons-have the capacity to provide a means of identifying genetic relationships between individuals sufficient to conclude that their retention interferes with the right to the private life of the individuals concerned. ${ }^{49}$ The Court reiterated that it was essential to have clear, detailed rules governing the scope and application of measures, as well as minimum safeguards concerning, inter alia, duration, storage, usage, access of third parties, procedures for preserving the integrity and confidentiality of data and procedures for its destruction, thus providing sufficient guarantees against the risk of abuse and arbitrariness. ${ }^{50}$

Unlike DNA matches used in criminal investigations, human identification efforts require the informed consent of the donor of the DNA sample. In turn, this requires an established purpose for the biological sample collection, the subsequent DNA extraction, storage and analysis via specialized software in a database, and the final disposition of the sample and the DNA profile after an identification has been generated. The donor consent form generally details the purpose of the biological sample collection and requests permission for a donor's DNA profile and any personal information necessary for identifications to be "placed in a confidential registry or database for identification and statistical analysis." ${ }^{51}$

The centralization of genetic profiles in a database is necessary to perform the statistical analysis that leads to profile matches, which is done via specialized software programs made for this purpose. For verification purposes, the profile matches equally need to be compared against other personal identifying information-such as secondary means of identification. This in turn requires legal safeguards against the information and data to be used for anything else other than for identification purposes. Such safeguards set human identification databases in mass fatalities apart from criminal investigative DNA databases, and thus these safeguards guarantee that other than for identification and repatriation of remains, the information will not be used to the detriment of the donor and/or their families.

An important consideration in conflict mass fatalities is the right to truth, which may entail criminal investigations at some stage. This necessitates balancing the protection of personal and confidential data with information release, often in a context in which legal systems have collapsed and privacy and data protection laws may not be in existence.

\section{Genetic Privacy}

For the purposes of human identification efforts, genetic testing primarily relies on extracting DNA profiles from nuclear DNA of a person's biological sample. The particular genetic characteristics that are analyzed are called "Short Tandem Repeats" (STRs). STR DNA profiles consist of a series of

\footnotetext{
${ }^{46} S$ and Marper v United Kingdom (European Court of Human Rights, Grand Chamber, Application Nos 30562/04 and 30566/04, 4 December 2008).

${ }^{47}$ Ibid., 73.

${ }^{48}$ Ibid., 73.

${ }^{49}$ Ibid., 75 .

${ }^{50}$ Ibid., 99.

${ }^{51}$ National Institute of Justice, Mass Fatality Incidents: A Guide for Human Forensic Identification (Washington, DC: National Institute of Justice, 2005), 65.
} 
numbers and do not contain any relevant information regarding genetic indicators of disease. On their own, these DNA profiles can only be used to establish paternity and kinship relations among relatively close family members. A second type of DNA analysis used in determining human identity via family relationships is mitochondrial and Y-chromosome testing. This type of DNA is more useful in making linkages to inheritable diseases, but this is dependant on known diseases existing in ancestors. This again doesn't identify actual inherited genes which are associated with particular diseases. None of these tests even examine areas of the DNA strand that have been demonstrated to code for diseases, nor do the laboratory processes use methods to isolate genes relevant to diseases or other genetic characteristics that are linked to behavior or ethnicity. The only discrimination that might arise is one that is based on known personal information of someone identified via DNA profile matching, not on what is visible in the string of numbers that represents their DNA profile.

There is the potential in examining what are called Single Nucleotide Polymorphisms (SNPs) in DNA to determine things such as inherited genetic traits. Due to the ability of laboratories to extract DNA from degraded biological samples, this has begun to play an important role in human identification efforts. Using the appropriate laboratory process, this type of DNA extraction can be used to determine things such as inheritance of diseases, skin and eye color, and their physical characteristics. However, for human identification purposes, the information that is extracted by the laboratory and then examined contains no real personal or private information about the donor. ${ }^{52}$ The laboratory extraction processes used in SNP DNA analysis for human identification purposes, much like STR DNA analysis, do not even isolate information that might be considered information relating to personal information of the donor of the biological sample. Such information simply isn't necessary.

DNA profiles used in human identification efforts are different from genome sequencing, which is the actual 'printout' of the entire genetic strand of a person. DNA profiles look at small portions of a person's DNA, and particularly at those portions that do not contain any information relevant to things such as what is expressed in a person's genome. From an identity perspective, they only become important when they are related to either the parents, or close family members. Association with disease, or other genetic traits (for example, eye or hair color, specific behaviors) cannot be made based on these genetic profiles alone. In other words - the genetic profile extracted for human identity testing in nuclear, mitochondrial, Y-chromosome, and SNP DNA analysis in and of itself does not yield or look at any genetic information that could be used to discriminate against the individual.

Such DNA profiles are only really useful to establish kinship between parents and a child, or between a person and their closer relatives, e.g. brothers/sisters, or even uncles/aunts and possibly cousins. The series of numbers that represent a single DNA profile doesn't by itself provide any relevant personal information. The DNA profile only becomes relevant when it provides information on relationships to people that are known to exist-on whom there are civil identification records tied to an existing person. Any information that could be used to discriminate is based on the knowledge of such relationships. Knowledge of such relationships can be used for discriminatory purposes, for example ethnic profiling. A good example is when genetic information reveals unknown relationships, such as a child not being biologically related to the father. Uncontrolled release of such information can have devastating effects, the worst being in contexts where adultery is considered a crime and punished as such, and in some cases could lead to so-called honor killings. The responsibility to protect people from such devastating effects is great and provides the basis for the argument to securely limit access to DNA profile databases and their analytical results.

Genetic Privacy at the International Commission on Missing Persons

The International Commission on Missing Persons (ICMP) was established in 1996 on the initiative of then US President Bill Clinton with the aim of securing the cooperation of governments to

\footnotetext{
${ }^{52}$ Bruce Budowle and Angela Van Daal, "Forensically relevant SNP classes," BioTechniques 44, no. 5 (2008).
} 
locate missing persons in the former Yugoslavia. ${ }^{53} \mathrm{ICMP}$ has since emerged as an impartial global organization undertaking individual human identifications in a variety of contexts around the world.

In one of its information sheets the organization states that ICMP's mandate and work is separate and distinct from that of criminal justice institutions. ${ }^{54}$ The organization nevertheless recognizes: ${ }^{55}$

ICMP's policies provide that personal data must be adequate, relevant and not excessive in relation to the purposes for which it is collected and processed. In addition, it may not be retained longer than necessary. It is clear, however, that in missing persons' processes generally, and in the context of war crimes, crimes against humanity and genocide in particular, forensic evidence may have to be kept for a greatly extended period of time.

Obtaining data subject consent thus requires implementing a commensurate measure of protection. Such protections have been provided through granting ICMP, its premises, data processing systems and communications privileges and immunities under domestic and international law.

ICMP extends the protection of the genetic profiles to denying donors access to their own profile for uses other than identification purposes. ${ }^{56}$ Furthermore, genetic profiles are encrypted to protect a donor's genetic privacy. In addressing criminal investigative needs, the organization states that it does not make personal information in its possession available without the consent of family members of missing persons. ${ }^{57}$ If necessary, however, ICMP may provide a DNA profile or other personal information to a public authority mandated to address missing persons cases for which the DNA sample is being requested, provided that public authority observes adequate standards of data protection with regard to genetic and other personal data and provides credible assurance that it will not use the data for purposes other than those for which it has been provided to ICMP without the donor's consent. ${ }^{58}$

The ICMP bases its justification and need for genetic privacy on the argument that genetic testing may identify a disease for which there is no cure or find a gene mutation which may cause or increase the risk of a disorder and that this information could fall into the hands of a wrong person. The spectre of genetic discrimination, which could be based on knowledge of such gene mutations, is also raised. By this line of argument, the ICMP asks donors to release the organization "from any obligation to provide you or any other party with the results of genetic analysis performed by ICMP." 59

The argument that concerns for genetic privacy vis-a-vis information contained in a person's genome does not apply when it comes to DNA analysis in human identification efforts. Where it does apply is in the disposition of a person's biological sample, from which a person's entire genetic sequence could be obtained. In the context of human identification efforts this isn't done and isn't necessary. It is therefore important that a clear distinction be made between what information can be gained from DNA profiles generated for human identification purposes and what type of DNA extraction is done with the biological sample. The discussion of the right to privacy in this context is more relevant to the disposition and potential use of the biological sample, rather than the actual DNA profile.

${ }^{53}$ Jeremy Sarkin, Lara Nettelfield, Max Matthews, and Renee Kosalka, Bosnia and Herzegovina, Missing Persons from the Armed Conflicts of the 1990s: A Stocktaking (Sarajevo: International Commission for Missing Persons, 2014), 34.

${ }^{54}$ International Commission on Missing Persons, "DNA Genetic testing and processing information sheet," February 3, 2016, accessed March 20, 2017, http://www.interno.gov.it/sites/default/files/allegati/icmp st ls 2994 doc-scheda dna.pdf.

${ }^{55}$ International Commission on Missing Persons, “Data Protection," 2017, accessed March 20, 2017, http://www.icmp.int/ the-missing/approaches-and-standards/data-protection/.

${ }^{56}$ International Commission on Missing Persons, DNA Genetic testing and processing information sheet.

${ }^{57}$ International Commission on Missing Persons. "DNA Reports Guide," December 16, 2010, accessed March 20, 2016, https://www.icmp.int/wp-content/uploads/2015/04/icmp-fsd-dna-50-2-doc.pdf.

${ }^{58}$ International Commission on Missing Persons, DNA Genetic testing and processing information sheet.

${ }^{59}$ Ibid. 
Changing the Genetic Privacy Discourse

The discourse around genetic privacy-and what is perceived as genetic privacy-needs to be closely examined and questioned when it is used to justify genetic databases being given immunity from judicial inquiry. Our intent in calling for such examination is not to diminish the need for witness and family members' protection and privacy. This is imperative. Rather it is to ensure that the rights of witnesses and family members are balanced with the rights of an accused person to a fair trial, a necessary component of which is the ability to test the evidence against them. In war crimes trials this basic principle takes on increased importance as the perception of bias by the court or tribunal can lead to accusations of victors' justice and further instill existing divisions within the affected society. A proper legal framework and use of legal mechanisms designed to balance victim and witness privacy concerns with prosecutorial disclose obligations could prevent the abuse of such human identification databases. Although this won't always be feasible, it should not be assumed that a country is incapable and/or unwilling to provide such mechanisms.

The key to matching DNA profiles is the database and its analytical capability (software) to properly identify kinship relations between individuals to the point where a positive identification can be made. As outlined previously, this needs to be verified via the antemortem data which is collected in the field. Separating the database and its analytical capability from the local jurisdiction therefore runs the risk of leading to miscommunications that can complicate any discrepancy issues that might arise. This can result in DNA matches made public before they are verified by the antemortem information, or simply because biological sample collection in the field is inadvertently contaminated, or samples switched, leading to DNA matches which aren't correct (misidentification) or delays and miscommunication in informing families about identifications that have been made. This is particularly pertinent in environments where the language used between those that control the DNA profile database and analysis is different from the one spoken in the local jurisdiction. DNA human identification databases start with a few cases, to which more are added over time, depending on the scope of the mass fatality. Starting such a database outside of a national jurisdiction may introduce a de-facto situation where the ownership of such a database and its software is not legally defined, resulting in a national effort that has no jurisdiction over the database and the necessary software. Since the DNA profile on its own renders little information about a person, it is much more important to determine who controls the analysis of the DNA samples stored in the database early on in the human identification process.

\section{The International Legal Framework for the Identification of the Missing and Repatriation of the Dead}

The duty to search for the dead was first codified in respect of international armed conflicts in the 1929 Geneva Convention for the Amelioration of the Condition of the Wounded and Sick in Armies in the Field..$^{60}$ It was subsequently codified in respect of international armed conflicts in the Geneva Conventions of 1949 and in respect of non-international armed conflicts in Additional Protocol II to the Geneva Conventions. ${ }^{61}$

The Geneva Conventions of 1949 prescribe examination of the bodies, if possible by medical examination, with a view to confirming death, establishing identity and enabling a report to be

\footnotetext{
${ }^{60}$ Art. 3, opened for signature 27 July 1929, 118 LNTS 303, entered into force 19 June 1931.

${ }^{61}$ Geneva Convention for the Amelioration of the Condition of the Wounded and Sick in Armed Forces in the Field, Art. 15, opened for signature 12 August 1949, 75 UNTS 31, entered into force 21 October 1950 ("First Geneva Convention"); Geneva Convention for the Amelioration of the Condition of Wounded, Sick and Shipwrecked Members of Armed Forces at Sea, Art. 18, opened for signature 12 August 1949, 75 UNTS 85, entered into force 21 October 1950 ("Second Geneva Convention"), Geneva Convention relative to the Protection of Civilian Persons in Time of War, Art. 16, opened for signature 12 August 1949, 75 UNTS 287, entered into force 21 October 1950 ("Fourth Geneva Convention"), Protocol Additional to the Geneva Conventions of 12 August 1949, and relating to the Protection of Victims of NonInternational Armed Conflicts, Art. 8, opened for signature 8 June 19771125 UNTS 609, entered into force 7 December 1978 ("Additional Protocol II"). See also International Committee of the Red Cross (ICRC), Customary International Law (ICRC), Rule 112, accessed March 20, 2017, https://ihl-databases.icrc.org/customary-ihl/eng/docs/v1 cha chapter35 rule112. State practice establishes this rule as a norm of customary international law applicable in both international and non-international armed conflicts.
} 
made. ${ }^{62}$ State practice also establishes a customary rule that parties to an international armed conflict must endeavour to facilitate the return of the remains of the dead (and their personal effects) upon the request of the party to which they belong, or their next of kin. ${ }^{63}$ There is growing recognition of this rule in the context of non-international armed conflicts. Articles 33 and 34 of Additional Protocol I outline obligations with respect to missing persons and remains of deceased persons respectively, with the implementation of those obligations by States, parties to the conflict and international humanitarian organizations to be "prompted mainly by the right of families to know the fate of their relatives." These words, found in Article 32 of Additional Protocol I, represent the first codification of the right to the truth.

\section{The Right to the Truth}

The right of families to know the truth surrounding the fate of a missing family member codified in Article 32 of Additional Protocol I to the Geneva Conventions ${ }^{64}$ is recognised as a norm of customary international law applicable to all parties in both international and non-international armed conflicts. ${ }^{65}$

In the human rights context, the right to the truth is most often invoked in relation to enforced disappearances, one of the elements of which is a refusal to acknowledge the deprivation of liberty or concealment of the fate or whereabouts of the disappeared person, placing that person outside the protection of the law. The International Convention for the Protection of All Persons From Enforced Disappearance ${ }^{66}$ expressly provides for the right of any victim, the definition of which includes relatives of a disappeared person, to know the truth about the circumstances of an enforced disappearance and the fate of a disappeared person. ${ }^{67}$

International human rights bodies have extended the right to the truth to the circumstances of serious human rights violations in general. In its study on the right to the truth, the OHCHR concluded that:

The right to the truth about gross human rights violations and serious violations of human rights law is an inalienable and autonomous right, linked to the duty and obligation of the state to protect and guarantee human rights, to conduct effective investigations and to guarantee effective remedy and reparations. This right is closely linked with other rights and has both an individual and societal dimension and should be considered as a non-derogable right and not be subject to limitations. ${ }^{68}$

The suffering experienced by the families of the disappeared by a refusal to provide them with information about the whereabouts or fate of a disappeared person has been recognised as

${ }^{62}$ First Geneva Convention, Art. 17; Second Geneva Convention, Art. 20; See also Geneva Convention relative to the Treatment of Prisoners of War, opened for signature 12 August 1949, 75 UNTS 135, entered into force 21 October 1950, Art. 120 ("Third Geneva Convention"); Fourth Geneva Convention, Art. 129.

${ }^{63}$ ICRC, Customary International Law, Rule 114, accessed March 20, 2017, https://ihl-databases.icrc.org/customary-ihl/eng/ docs/v1 rul rule114. See also First Geneva Convention, Art. 17; Third Geneva Convention, art 120, Fourth Geneva Convention, Art. 130.

${ }^{64}$ Protocol Additional to the Geneva Conventions of 12 August 1949, and relating to the Protection of Victims of International Armed Conflicts, opened for signature 8 June 1977, 1125 UNTS 3, entered into force 7 December 1978 ("Additional Protocol I").

${ }^{65}$ ICRC, Customary International Law, Rule 117, accessed March 20, 2017, https://ihl-databases.icrc.org/customary-ihl/eng/ docs/v1 rul rule117.

${ }^{66}$ Opened for signature 6 February 2007, 2716 UNTS 3, entered into force 23 December 2010.

${ }^{67}$ Preamble, Arts. 18 and 24(2).

${ }^{68}$ OHCHR, Promotion and Protection of Human Rights: Study on the Right to the Truth, UN Doc E/CN.4/2006/91, 8 February 2006. See also: Diane Orentlicher, Report of the independent expert to update the Set of Principles to combat impunity, Addendum, "Updated set of principles for the protection and promotion of human rights through action to combat impunity," UN Doc E/CN.4/2005/102/Add.1, 8 February 2005, which updates the "Joinet principles": Un Doc E/CN.4/ Sub.2/1997/20/Rev.1, Annex II. 
a human rights violation by regional human rights courts. ${ }^{69}$ In Croatia $v$ Serbia ${ }^{70}$ the International Court of Justice held that "the psychological pain suffered by the relatives of individuals who have disappeared in the context of an alleged genocide, as a result of the persistent refusal of the competent authorities to provide the information in their possession which would enable these relatives to establish with certainty whether and how the persons concerned died, can in certain circumstances constitute serious mental harm within the meaning of Article II (b) of the Convention." ${ }^{71}$ The ICTY has also held that the suffering experienced by family members in not knowing what had happened to their missing family members in the context of genocide itself amounts to serious mental harm as an act of genocide. ${ }^{72}$

The right of individuals, families and communities to know the truth about the identity of victims and the circumstances of mass fatalities is integral to any human identification effort. In countries experiencing or emerging from armed conflict it also provides the foundation for any legitimate transitional justice effort. The role of the State is integral as it is the State that makes the ultimate decision to identify an individual and confirm their death. Any foreign actorswhether private service providers, NGOs or UN auspiced bodies-need a clear exit strategy that includes developing the necessary conditions for handover of human identification operations to local authorities at some point. Not addressing such an exit strategy at the onset of a human identification effort in conflict-affected and post-conflict settings runs the risk of counteracting any national efforts to address the right of families to know the truth surrounding the fate of missing family members. Divorcing human identification efforts from the right to truth can feed into political efforts that are discriminatory against certain groups or that altogether ignore truth seeking, factors which may contribute to ongoing cycles of violence.

The Right to the Truth and the Role of NGOs

Despite the early codification of the obligation to search for and repatriate the dead in the context of international armed conflicts, the issue of repatriation of remains in the context of civil wars and following repressive regimes has been primarily advanced by civil society movements in affected societies.

States experiencing or emerging from armed conflict face many challenges, not least the reestablishment of order and the rule of law. Such states rarely if ever, have the necessary forensic infrastructure in place to deal with the mass fatalities that have occurred. Even where capacity does exist, governments may be unwilling to support a human identification effort due to its own involvement in crimes, perpetrators continuing to occupy positions of power, or a belief that addressing past crimes will destabilise a transition to peace.

In many states experiencing or emerging from armed conflict or periods of egregious human rights violations witnesses won't come forward to government authorities to have their testimonies recorded out of fear of reprisals by the perpetrators, who often remain in power and benefit from a culture of impunity. Lists naming missing persons, along with accounts of massacres and summary executions by witnesses, are sensitive information that, if released openly, could lead to reprisals against victims' families and their communities. In such circumstances it is not uncommon for NGOs who gain the trust of witnesses to emerge as an alternative repository of witness accounts, as well as the safeguard of data and witness privacy.

Family associations in affected communities were among the first to collect and safeguard such information. They also became the focal and entry point for the forensic NGOs that were established

\footnotetext{
${ }^{69}$ Kurt v Turkey, European Court of Human Rights, Chamber, Application No 24276/94, May 25, 1998, para. 134; Bazorkina $v$ Russia, European Court of Human Rights, Chamber, Application No 69481/01, July 27, 2006, para. 146. See also Velásquez Rodríguez v Honduras, Inter-American Court of Human Rights (Ser C) No 4, July 29, 1988.

${ }^{70}$ Application of the Convention on the Prevention and Punishment of the Crime of Genocide (Croatia v Serbia) International Court of Justice, February 3, 2015.

${ }^{71}$ Paras. 356 and 160.

${ }^{72}$ Prosecutor v Karadžić, Trial Chamber Judgment, March 24, 2016, IT-95-5/18-T, para. 5664-5665; Prosecutor v Blagojević and Jokić, Trial Chamber Judgment, January 17, 2005, IT-02-60-T, para. 653; Prosecutor v Popović, Trial Chamber Judgment, June 10, 2010, IT-05-88-T, para. 846.
} 
in the late 1980s and early 1990s in Latin America. Some of these NGOs, including the Argentine and Guatemalan Forensic Anthropology Teams, ${ }^{73}$ earned the trust of these family associations and gained legitimacy. At the time, the principal means of identification rested on methodologies rooted in forensic anthropology. Positive identifications, if they were even possible, were based on the comparison of body landmarks found in the skeletal remains with the antemortem data that had been collected from victims' families and witnesses.

By effectively privatizing forensic exhumations and identifications, some actors and victims' families undoubtedly felt that their right to truth was addressed without the need to wait for the state to lead such efforts. The NGOs could provide immediacy in responding to repatriating the dead and the right to truth where the state could not. Privatisation may also provide a means to empower victims of human rights violations who are advocating for the truth to be told in a climate of impunity in which official acknowledgement is not forthcoming. In Spain the government itself abrogated its obligations under international human rights law and through the Law on Historical Memory effectively privatised human identifications, granting subsidies to individuals and NGOs willing to perform the search, identification and exhumation of mass graves. However, State granting of subsidies to NGOs to perform these activities cannot replace the State's duty to investigate disappearances and offer integral reparations to the victims. ${ }^{74}$ Further, the law remains silent as to what happens postexhumation when there is a need for identification with families generally left to cover the expenses with their own resources, although in some cases subsidies have also been used to pay these expenses. ${ }^{75}$

Undoubtedly NGOs are an important actor in the human rights and human identification landscape. However, human rights, including the right to the truth, remain the overall responsibility of the State. The work of private DNA labs to match profiles and identify a set of remains in that way cannot fulfil the right to the truth, the essence of which is State acknowledgment of what happened. The DNA lab can provide a positive DNA match but it can't tell you what happened, when, how, why, or by whom. And it can't formally acknowledge the truth of what happened. Even if combined with credible NGO documentation efforts, state acknowledgement is key to the right to the truth. Most importantly though, where human rights NGOs are taking the lead in doing this work, such as the EAFG/FAFG in Guatemala, they are located within the host country's jurisdiction and work within the national legal system.

\section{Human Identifications in Armed Conflicts: Case Studies}

In this section we present a number of case studies illustrating the above-mentioned challenges of conducting human identification efforts in countries experiencing or emerging from armed conflicts.

\section{Guatemala}

The first mass grave exhumations in Guatemala were conducted in 1992 under the then EAFG. The objective was to exhume and document the suffering of the victims of the country's civil war in the 1980s, many of who were buried in mass graves. The primary drivers were family associations, who wanted the victims' remains repatriated, and above all, to have the truth told. These first exhumations in the Department of El Quiché of sites at Chontolá and San José Pacho Lemoa were carried out in accordance with judicial orders and the under the direction of the regional medical examiner of the Department of El Quiché in 1992, Dr Garcia de Crocker and her assistant, Flavio Montufar. Dr Crocker was particularly supportive of a forensic anthropology team, as she wasn't receiving any support from the central government in Guatemala City. This relationship with the medical examiner in El Quiché was the foundation that led to the formation of EAFG with funding

\footnotetext{
${ }^{73}$ Equipo Argentino de Antropología Forense (EAAF) and the Equipo de Antropología Forense de Guatemala (EAFG), which in 1997 became the Fundación de Antropología Forense de Guatemala (FAFG).

${ }^{74}$ Patricio Galella, "Privatising the search and identification of human remains: the case of Spain," Human Remains and Violence 1, no. 1 (2015), 62.

${ }^{75}$ Ibid.
} 
received from the American Association for the Advancement of Science's Human Rights and Science Program.

To document what had happened and lend credibility to witness statements taken by the team during the antemortem interviews with surviving family members, it was necessary for the EAFG to link the victims in the mass graves to the survivors and their accounts. There was also a need to individually identify human remains, not only to repatriate them to their families, but also to provide evidence that specific individuals had been killed in the incidents that were reported by witnesses. This in turn required witnesses to trust the EAFG to collect, store, and analyse this information while protecting the data from misuse.

In the early 1990s positive identifications of individual human remains with the help of DNA were not possible. The technology was just beginning to develop and was inaccessible in countries like Guatemala. Compounding any human identification effort was the fact that the victims in Guatemala were generally from a population that had very limited access to healthcare and as a consequence there were no dental X-ray records or other medical records on file to assist in the identification of remains. Following the exhumations, very few positive identifications were achieved by the EAFG on the basis of comparisons of antemortem interview data from surviving family members and the data derived from the postmortem forensic examinations.

Positive identifications were limited to a comparison of the biological profile established by forensic anthropologists in the lab with the antemortem information, taking into account secondary means of identification. They were relatively few and limited to those contexts where the burial of those that had been killed as a result of human rights violations were relatively controlled. That is, surviving family members were able to identify the mass graves and testify to the identities of those in the grave as they often had buried the victims themselves. At that point, biological profiles (i.e. age, sex, stature, handedness, individual dental/medical traits) were used to distinguish individuals that had been reported in that grave. If these biological profiles varied sufficiently to distinguish between the individuals that were exhumed from the grave, the antemortem data and secondary means of identification (e.g. description of the burial, clothes worn by victims at the time of burial, etc.) were justification enough to generate a positive identification. Even though these deaths by no means occurred under controlled circumstances, the identification process was based on the concept that the context of the mass grave was sufficiently controlled by witness statements in order to allow for positive identifications without primary means of identification. ${ }^{76}$ Based on this methodology, some positive identifications were generated by EAFG for the mass graves exhumed in the 1990s. Many of the exhumed remains though could not be identified this way and were repatriated to their communities without identification for communal burial. These communal burials allowed communities to grieve, to bury their dead with dignity and also served as a form of memorializing the truth as documented by the NGO team of forensic anthropologists and archaeologists.

The Guatemalan experience highlights the importance of access to surviving witnesses and family members and gaining their trust that the information they provided wouldn't be used against them by the perpetrators, most of which were free and remained in power. EAFG established itself as a forensic support NGO to the Legal Medicine Department and its staff were judicially appointed as experts for the families requesting the exhumation of the remains of their loved ones. To those involved, it was clear that truth and justice could only be achieved within a judicial framework, even if this meant working within a corrupt judicial system that was skewed towards maintaining silence about the crimes of the former regimes that continued to hold military power in the country. From the start, those that founded EAFG believed that working within the judicial system would be key to any future trials.

Today, FAFG's experts regularly testify in domestic trials in Guatemala. Key to the organization's evolution has been its ability to build upon existing levels of trust with victims' families and maintain ownership of the database and analytical software enabling them to produce DNA matches and positive human identifications within a national investigative and legal framework.

\footnotetext{
${ }^{76}$ This would include a list of the dead in a mass grave, sufficient variety in biological profiles reported in antemortem data (i.e. age, sex, stature, handedness, dental/medical traits), and a description of clothing worn at burial.
} 
The Former Yugoslavia

Unlike Guatemala, the armed conflict in the former Yugoslavia, perhaps due to its geographical location in Europe, garnered international attention. On October 6, 1992 the UN Security Council in Resolution 780 established a Commission of Experts to examine and analyse information gathered with a view to providing the Secretary-General with its conclusions on evidence of grave breaches of the Geneva Conventions and other violations of international humanitarian law committed in the territory of the former Yugoslavia. ${ }^{77}$ Physicians for Human Rights (PHR) provided a team of international forensic experts, including the first author, to the Commission, whose work was to inform the nascent International Criminal Tribunal for the former Yugoslavia (ICTY).

The ICTY was established under Chapter VII of the UN Charter in May 1993 and empowered to prosecute persons responsible for serious violations of international humanitarian law committed in the territory of the former Yugoslavia since 1 January 1991. The tribunal exercises jurisdiction over grave breaches of the Geneva Conventions of 1949, violations of the laws or customs of war, genocide and crimes against humanity. ${ }^{78}$

Over five years from 1996-2001, the ICTY investigated and exhumed a number of mass graves. These investigations were primarily focused on the gathering of evidence necessary to prosecute war crimes, crimes against humanity and genocide. For ICTY investigators, the group identity of victims was important to establishing the elements of crimes against humanity and genocide. Evidence of the identity of individual victims was considered of lesser importance than the evidence necessary to establish the "broad pattern or practice of the commission of such crimes for reasons of political, ethnic, or religious persecution." ${ }^{\prime 79}$ Mass grave sites were exhumed on the basis of their link to an existing indictment, or ongoing investigation where it was felt an indictment would be issued..$^{80}$ There was little consideration given to understanding the enforcement of humanitarian law as one aspect of a larger project of healing the psychological wounds resulting from armed conflict. ${ }^{81}$ As a result, many families were denied information about their loved ones, not because it was unascertainable, but because investigations were handled improperly. ${ }^{82}$

PHR carried out the first exhumation for the ICTY in the Srebrenica area in July of 1996. Early on though, PHR recognized the need for scientifically sound identification of those that were exhumed in order to address the clamoring of families searching for the missing-something that the ICTY wouldn't address. In addition to its obligations to provide forensic expertise to the Tribunal, PHR began compiling an antemortem database of suspected victims in Srebrenica. The first identifications of Srebrenica victims were made in 1997, following which the database effort was expanded to include information from missing persons elsewhere in Bosnia. These identifications were supported by PHR's antemortem data base effort, using mitochondrial DNA analysis to confirm cases where antemortem wasn't sufficiently conclusive. ${ }^{83}$ By 1998 about 30 identifications had been carried out in this manner. ${ }^{84}$

This first identification effort driven primarily by local forensic pathologists was integrated into ICMP's operations in 1999. In November 2001, ICMP obtained its first DNA match leading to an identification of a set of remains. Prior to that, identifications were primarily made utilising "traditional" methods of anthropological examinations, visual inspection of remains by family

\footnotetext{
77 United Nations, Final Report of the Commission of Experts Established Pursuant to Security Council 780, May 27, 1994, UN Doc. S/1994/674.

${ }^{78}$ United Nations, Statute of the International Criminal Tribunal for the former Yugoslavia, May 25, 1993, UN Doc S/ RES/827.

${ }^{79}$ Aryeh Neier, War Crimes: Brutality, Genocide, Terror, and the Struggle for Justice (New York: Random House, 1998$), 17$.

${ }^{80}$ Admir Jugo and Senem Skulj, "Ghosts of the past: The competing agendas of forensic work in identifying the missing across Bosnia and Herzegovina," Human Remains and Violence 1, no. 1 (2015), 43.

${ }^{81}$ Jose Pablo Baraybar, Valerie Brasey and Andrew Zadel, "The Need for a Centralised and Humanitarian-based Approach to Missing Persons in Iraq: An Example from Kosovo," The International Journal of Human Rights 11, no. 3 (2007), 266.

${ }^{82}$ Ibid., 269.

${ }^{83}$ Laurie Vollen, "All That Remains: Identifying the Victims of the Srebrenica Massacre," Cambridge Quarterly of Healthcare Ethics 10, no. 3 (2001), 339.

${ }^{84}$ Ibid., 339.
} 
members, witness interviews and the comparison of medical and dental records. As of 31 July 2014 just under 23000 identifications had been made with 14792 being made through DNA-assisted methods and a further 8192 being made through "traditional" methods. ${ }^{85}$

In any human identification effort there is a need for a robust security, privacy and evidentiary framework in order to protect data, DNA profiles, biological samples and safeguard victim and witness information. This is a challenge in any context, but particularly challenging in states experiencing or emerging from armed conflict where perpetrators may still be in power, were impunity may still reign, and where the necessary infrastructure, resources, capacity and funding are lacking. In Bosnia, as in many states experiencing or emerging from armed conflict, there was no domestic legal framework governing the use of DNA evidence. Instead, the State used an international agreement with the ICMP "to compensate for a gap in domestic capacity by assigning a public investigative function to an international public organization capable of performing that function." ${ }^{86}$

The ICMP's efforts to ensure data protection and safeguard the privacy of witnesses and families led to the establishment of unprecedented levels of immunity in separate agreements with the Council of Ministers of Bosnia and Herzegovina (1998) ${ }^{87}$ and the Government of Croatia (2002). ${ }^{88}$ The Headquarters agreement provides immunity for property, assets, and staff of the ICMP from "every form of legal and administrative process, except insofar as in any particular case the ICMP has expressly waived its immunity." ${ }^{89}$ It also provides for the inviolability and immunity of ICMP premises, property and assets from "search, requisition, confiscation, expropriation, and any other form of interference, whether by executive, judicial, administrative or legislative action." 90 Practically, this also meant that biological samples and profiles became the property of the ICMP as a means to protect witness information and data. Only the ICMP could decide on whether information was to be shared with authorities or not. Compliance with writs such as a subpoena compelling production of material or witness attendance to give evidence was subject to the ICMP waiving their immunity. In other words, the ICMP received diplomatic status as a technical and scientific human identification operation. For a DNA laboratory or human identification effort, this was unprecedented.

Radovan Karadžić challenged ICMP's identification methodology and approach to safeguarding data and privacy during his trial on genocide, war crimes and crimes against humanity charges at the ICTY. In determining the number of dead in the Srebrenica mass graves the Chamber relied heavily upon ICMP's DNA identification data. This was an important part of the Chamber's assessment as to whether the intent to destroy at least a substantial part of a particular group required for genocide could be inferred from the factual circumstances. ${ }^{91}$ Although there is no numeric threshold to be reached for mass killings to constitute genocide, ${ }^{92}$ and what is

\footnotetext{
${ }^{85}$ Sarkin et al, Bosnia and Herzegovina, 11. These identifications reportedly represent around 70\% of those missing as a result of the armed conflict: 21.

${ }^{86}$ See International Commission on Missing Persons, "Bosnia and Herzegovina," June 18, 2014, accessed March 21, 2017, https://www.icmp.int/where-we-work/europe/western-balkans/bosnia-and-herzegovina/.

${ }^{87}$ International Commission on Missing Persons, "Headquarters Agreement between the International Commission on Missing Persons and the Council of Ministers of Bosnia and Herzegovina," April 26, 1998, accessed March 21, 2017, http://www.icmp.int/wp-content/uploads/2014/08/hq-agreement-with-bih-mofa.pdf.

${ }^{88}$ International Commission on Missing Persons, "Agreement between the International Commission on Missing Persons and the Government of the Republic of Croatia regarding the status of the International Commission on Missing Persons office in the Republic of Croatia," September 3, 2002, accessed March 21, 2017, http://www.icmp.int/wpcontent/uploads/2014/08/agreement-icmp-roc.pdf.

${ }^{89}$ ICMP Headquarters Agreement, Art 3.

${ }^{90}$ Ibid., Art 4.

${ }^{91}$ Prosecutor v Krstić, Appeals Chamber Judgment, April 19, 2004, IT-98-33-A, paras. 8, 12, 34; Draft Code of Crimes against the Peace and Security of Mankind with Commentaries in Report of the International Law Commission on the work of its fortyeighth session 6 May - 26 July 1996 (UN Doc A/51/10) Article 17, Comment (8).

${ }^{92}$ Prosecutor v Semanza, Trial Chamber Judgment, May 15, 2003, ICTR-97-20-T, para. 316; Prosecutor v Stakić, Trial Chamber Judgment, July 31, 2003, IT-97-24-T, para. 522.
} 
substantial can also be measured qualitatively, ${ }^{93}$ establishing the numeric size of the targeted part of the group is the necessary and important starting point for considering whether or it constitutes a "substantial part."

Over a number of years Karadžić unsuccessfully sought access to ICMP's database in full, or, in the alternative, the exclusion of all of ICMP's DNA analysis. While the Chamber agreed that Karadžić should be able to engage his own DNA expert and run DNA identification tests similar to those conducted by ICMP for the purposes of checking the accuracy of ICMP's identifications and challenging the evidence, ICMP refused to provide the database without obtaining the consent of the affected families, a process that would take a significant amount of time given the number of samples. An agreement by which Karadžić would have access to 300 cases fell through after the family members of 14 of these 300 victims refused to consent to their sample being disclosed. The Chamber refused to issue a binding order or subpoena to the ICMP compelling it to produce the material relating to those 14 cases on the grounds that the sample of 286 cases was sufficient for testing ICMP's results and challenging the evidence of the Thomas Parsons, ICMP's Director of Forensic Science. ${ }^{95}$

Karadžić fought a similar battle over 11 tendered documents provisionally admitted under seal during Parsons's evidence. ${ }^{96}$ The Prosecution argued that this was necessary on privacy grounds to protect the genetic information of the alleged victims and their family members, as well as their genetic relationships or lack thereof; prevent the public from knowing that certain family members had participated in the ICMP DNA identification process as they might not want this disclosed; and remove any possibility that family members may find out about the deaths of their relatives through the trial, as it appeared that several DNA matches that had been made years earlier had not led to family notifications at the time of the hearing. ${ }^{97}$ The Prosecution also argued that family members had become "unwitting witnesses" to the proceedings by donating their genetic material and were therefore entitled to the protections afforded victims and witnesses under Rule 75 of the Rules of Procedure and Evidence. ${ }^{98}$ The Chamber did not accept that family members had become "unwitting witnesses," however, it held, citing $S$ and Marper, that in light of "its highly sensitive and personal nature" the information relating to the genetic material of the alleged victims - extending to that of their family members - should be kept out of the public domain, if not under Rule 75, using the discretion afford the Chamber under Rule 54. The Chamber dismissed as "speculative at best" the Prosecution's submission that some family members might not want it known that they had participated in the DNA identification process. ${ }^{99}$ Further, the argument that family members should not find out from the proceedings that their relatives are dead needs to be assessed on a case-by-case basis. ${ }^{100}$ Where matches were made several years ago, the Chamber found it reasonable to assume that family members would have been informed of the death. ${ }^{101}$ The Chamber ordered the unsealing of seven exhibits containing no genetic data and ordered the prosecution to redact the remaining documents in dispute for genetic data and then tender them. ${ }^{102}$

\footnotetext{
${ }^{93}$ For example, an intent to destroy the most representative members of the targeted community may be significant enough to have an impact on the group as a whole: Prosecutor v Krstić, Appeals Chamber Judgment, April 19, 2004, IT-98-33-A, para. 8; Application of the Convention on the Prevention and Punishment of the Crime of Genocide (Bosnia and Herzegovina v Serbia and Montenegro), Judgment, ICJ Reports 2007, 43, para. 198; Prosecutor v Jelisić, Trial Chamber Judgment, December 14, 1999, Case No IT-95-10-T, para. 82. See also Prosecutor v Tolimir. Appeals Chamber Judgment, April 8, 2015, IT-05-88/2-A, 263.

${ }^{94}$ Prosecutor v Krstić, Appeals Chamber Judgment, April 19, 2004, IT-98-33-A, 19 April 2004, para. 12. See also para. 15. Cited with approval in Prosecutor v Popović, Appeals Chamber Judgment, January 30, 2015, IT-05-88-A, para. 493; Prosecutor v Tolimir, Trial Chamber Judgment, December 12, 2012, IT-05-88/2-T, para. 749.

${ }_{95}$ Prosecutor v Karadžić, Decision on the Accused's motion to exclude DNA evidence, Trial Chamber, April 16, 2013, IT-955/18-T, para. 7.

${ }^{96}$ Ibid.

${ }^{97}$ Ibid.

${ }^{98}$ Ibid.

${ }^{99}$ Ibid., para. 9.

${ }^{100}$ Ibid., para. 11.

${ }^{101}$ Ibid., para. 15-17.

${ }^{102}$ Ibid., para. 19.
} 
The Prosecution subsequently invoked Rule 70 of the Tribunal's Rules of Procedure and Evidence, that rule being an important rule, the purpose of which is to encourage states, organizations and individuals to share sensitive information with the Tribunal by guaranteeing protection to providers of that information and their sources. ${ }^{103}$ The Chamber ordered further redactions in respect of personal contact information of family members of alleged victims and of all references to 118 individuals involved in the most recent round of DNA matches, who had yet to be informed of the matches. ${ }^{104}$ The Chamber also ordered the Prosecution to liaise with ICMP and track the progress of notification of the families of these 118 individuals, with the exhibits to be reclassified as public once this has been done. ${ }^{105}$ In its concluding remarks the Chamber expressed "serious concern" regarding the Prosecution's practices for recording and disclosure of Rule 70 material. ${ }^{106}$

The Karadžić case highlights a number of issues. Firstly, that some family members had not been informed of DNA matches several years after they were made is possibly indicative of a communication problem somewhere along the chain. Clear communication between all actors is essential to mitigating the risk of any discrepancies that might undermine the legitimacy of the human identification effort. Secondly, distinctions can be drawn between different types of information accrued during the human identification effort and the level of protection to be afforded to them. Thirdly, the importance of clear, consistent and implemented standards in information flows and recording between those involved in all aspects of the identification, witnesses, family members, investigators and prosecutorial bodies. This is generally important in the administration of a fair trial and for ensuring that each of the actors involved knows where they stand. In the context of a war crimes trial it takes on added importance in allaying fears of victor's justice among those who may feel that the indictment of the Accused is an indictment of their entire community. Finally, a court with jurisdiction and an appropriate legal framework is best placed to adjudicate on and balance the competing right of victims and their families to privacy with prosecutorial disclosure obligations and the Accused's right to a fair trial.

\section{Libya}

Libya's revolution began on February 15, 2011 with demonstrations by family members of the 1, 276 prisoners massacred by the Qaddafi regime in Abu Salim prison in 1996. As the protests against the regime widened, so did the crackdown against them, leading to a full scale revolution. Following the collapse of the regime, on October 23, 2011 the revolutionary authorities declared "Liberation Day" with the capture and subsequent killing of Muhammar Qaddafi.

Early on, a quest began to not only locate the remains of the massacred prisoners of Abu Salim prison, but the many other victims of Qaddafi's 40 year regime, as well as to identify the remains of those that were killed during the revolution. In December 2011, the Ministry of Martyrs and Missing (MAFMM) was established to provide support to the families of the martyrs and missing and locate and identify the remains of those reported missing. Under MAFMM two departments were established: the Department of Martyrs' Affairs and the Department of Missing Persons' Affairs. The former was tasked with supporting martyrs and their families; and the latter with collecting data and identifying the remains of the missing and distributing financial support to martyrs' families. ${ }^{107}$

MAFMM was tasked with establishing a DNA laboratory to aid this effort. By March 2013, when PHR published its "Libyan Human Identification Needs Assessment and Gap Analysis," the Ministry had reportedly collected family DNA reference samples for approximately 2,100 reported missing cases. ${ }^{108}$ The number though was a reflection of those that felt comfortable reporting their

\footnotetext{
${ }^{103}$ Prosecutor v Karadžić, Decision on the Prosecution's Motion for Partial Reconsideration or Clarification of the Chamber's Decision on the Accused's Motion to Unseal ICMP Exhibits, Trial Chamber, September 5, 2012, IT-955/18-T, paras. 2-3.

${ }^{104}$ Ibid., paras.10, 19, 22.

${ }^{105}$ Ibid., paras. 25, 29.

${ }^{106}$ Ibid., para. 70.

${ }^{107}$ Schmitt et al, Libyan Human Identification, 15.

${ }^{108}$ Ibid., 37.
} 
missing loved one as a martyr, understood to be an individual, whether combatant or civilian, who had died at the hands of the Qaddafi regime. An unknown number of families who lost their loved ones fighting on the side of the Qaddafi regime did not feel able to report a missing family member due to fear of the potential repercussions of being associated with the deposed regime.

The political and social dynamics immediately after the revolution resulted in hastily and inexpert exhumations and collection of biological samples for eventual DNA analysis, often conducted extra judicially due to a breakdown of rule of law and in a political environment where existing national governmental institutions were struggling to remain relevant post-revolution. The urgency to recover and identify remains was in part due to the pressure of families seeking the repatriation of their dead and in part due to the need for the new Libyan society to honor those that had fought against the Qaddafi regime and liberated the Libyan people from its terror. A variety of ad-hoc local Missing Persons' Commissions were formed, each representing regional efforts by victim families around the major cities, such as Tripoli, Benghazi, and Misrata. The presence of unregulated local armed groups throughout the country also contributed to limiting the central government's ability to implement nationwide policies.

The dynamics surrounding the identification effort in Libya are perhaps best demonstrated by the example of what happened to the remains of those that had been killed fighting Qaddafi forces in early March 2011 in the town of Bin Jawad, close to Sirte. Initially there was a proper jurisdictional response to these deaths by the local medical examiner, who collected the remains that weren't claimed by families and reportedly kept them in a refrigerated container for four to five months in the hope of being able to repatriate them to their families. In the end, they were buried in Bin Jawad, but not before the local medical examiner had taken photographs of the bodies and their faces for identification purposes. The remains were reportedly buried in numbered graves, as the medical examiner had identified them in the photographs with the numbers to facilitate any future identifications made on the basis of facial recognition. There were reportedly 167 bodies which were assigned a number and buried.

In February 2012, political pressures on Libya's new government and MAFMM led to public demands to repatriate the unidentified remains of those killed in Bin Jawad to Benghazi, from where they reportedly originated. MAFMM had already begun collecting DNA samples and conducting exhumations at this time. After witnessing one of MAFMM's exhumations in Tripoli, a medical examiner at the Forensic Medicine Department there wrote to Libya's Prosecutor-General's Office raising concerns that these inexpertly conducted exhumations would result in damage to the remains to the extent that it would be very difficult, if not impossible, to determine cause and manner of death. ${ }^{109}$ Regarding the early collection of DNA samples, the medical examiner raised the point that any inconsistency in collecting DNA samples would require that both exhumation and collection efforts of such samples would have to be repeated at a later time, unnecessarily raising families' expectations of speedy identification and repatriation of remains. Despite the Prosecutor-General's Office suspending one such exhumation, MAFMM continued with its efforts.

In March 2012, MAFMM oversaw the exhumation of the remains that had been reburied by the local medical examiner in Bin Jawad the previous year. The primary purpose of this exhumation was the repatriation of the unidentified remains to Benghazi. Due to the intense pressure from families and politicians alike to repatriate the remains of these martyrs, the MAFMM went ahead with the re-exhumation of these remains, despite the first author's recommendations against it. In the end, out of the 167 numbered plots, 43 of the remains were reported to have been identified during the exhumation at the gravesite and taken away by family members.

The remaining majority of the remains were then taken to Benghazi and reburied as martyrs, again in numbered plots and after MAFMM had collected biological samples for DNA analysis. The first author made MAFMM aware it was likely that visual identifications made by families at the site of the exhumation were inherently unreliable and that the possibility of misidentifications needed to be taken into account in going forward with identifying the remaining bodies.

${ }^{109}$ Dr. Anwar Arbie correspondence with the Deputy General-Prosecutor's Office, February 26, 2012. 
Furthermore, collecting biological samples from both families and the remains was going to lead to heightened expectations that identifications of the unidentified remains were going to happen relatively quickly thereafter. Additionally, the lack of chain of custody over the samples and the reburied remains would require confirmatory testing upon attempting the repatriation of the reburied remains. MAFMM turned to the ICMP for support, who offered to process the samples and generate DNA matches in their lab outside of Libya as a means to expedite identifications.

The possibility that biological samples were to be sent outside of Libya for DNA testing and matching purposes raised concerns among several academics and scientists in the country, amongst them a Libyan geneticist who had returned from Canada and established a DNA laboratory in Tripoli. All of these individuals had advanced degrees from leading international universities. In a letter to Libyan authorities, including the Prime Minister, the Prosecutor-General, and others dated May 31, 2012, they raised the following concerns:

- That biological samples of the Libyan population were being transferred outside of the country's control, raising concerns about the misuse of these samples and their final disposition.

- That sending the samples outside of the country would not benefit the families in that it might not make the process of identifications any more expedient than using the laboratory in Libya, especially if re-sampling/testing would be necessary.

- The elevated cost of outsourcing the DNA testing.

- Outsourcing would ignore the necessary development of Libya's own national resources in human identifications.

The signatories also recommended that MAFMM coordinate with the established DNA laboratory at the Ministry of Interior and that biological samples should not be sent abroad until the National Safety and Biological Ethics Committee had given its permission. At the time, the MoI laboratory was able to extract DNA profiles from 192 samples per day. ${ }^{110}$ From this letter, the earlier letter of Tripoli's medical examiner regarding Bin Jawad, as well as a later stakeholder conference on April 4, 2013 on the role of truth seeking and human identifications held organised by the National Safety and Biological Ethics Committee, it was clear that Libya had the capacity and willingness to develop DNA human identification operations, as well as integrate them into the State's criminal investigation and truth seeking efforts. There certainly was no reason to exclude this expertise and infrastructure from the overall development of human identification expertise in the country, which would include developing a national database with the necessary analytical capabilities.

PHR's Human Identification and Needs Assessment also concluded that the bias at MAFMM towards those who were deemed martyrs was affecting the human identification effort in Libya. The report concluded that MAFMM's lack of cooperation with existing Libyan governmental institutions such as the Ministry of Interior, Ministry of Justice, and Prosecutor-General's Office, and with the legal framework, was detrimental to any potential criminal investigations. ${ }^{111}$

Despite these concerns, the biological samples were transferred to the ICMP and DNA profiles were extracted and analysed at their laboratory. The ICMP generated DNA matches were made between family reference samples and samples from the remains from Bin Jawad which had been reburied in Benghazi. On March 16, 2013 the ICMP issued a press release entitled "ICMP Submits 95 New DNA Match Reports to Libyan Authorities to Expedite Identification Efforts" in which

\footnotetext{
${ }^{110}$ Dr. Ahmed Elageili Zaid, Vice Dean of Faculty of Medicine, University of Tripoli; Dr. Abdullah Masoud be Sheen; Dr. Othman Abdel Jaleel Mohamed, Head of Forensic Laboratory Supervision Committee; Dr. Muftah Abdulatti al Fitoory, Professor, Faculty of Medizine, Benghazi University; Dr. Nabeel Sabri Enattah, Head of the Biotech Center, Tripoli, letter to Head of the NTC; the Prime Minister, Minister of MAFMM, Minister of MoI, Minister of MoEH, General Prosecutor, Head of the National Scientific Research Authority; Head of the Biological Ethics Committee; May 31, 2012.

${ }^{111}$ Schmitt et al, Libyan Human Identification, 49.
} 
they reported that they had matched 93 of the remains from Bin Jawad to families: "We hope that by expediting this process we will bring long awaited answers to families of the missing who have waited to learn the fate of their loved ones."112 Shortly after the press release, in conversation with MAFMM leadership over the identification effort, it became clear that the remains had yet to be exhumed for repatriation. ${ }^{113}$ Furthermore, MAFMM was uncertain about which buried remains corresponded to the samples that had been tested. As expected, their chain of custody over the numbering of the gravesite after the exhumation and transport of the bodies to Benghazi from Ben Walid was not as certain as they had thought.

The families, after having been informed about the DNA matches, were now rightfully demanding the repatriation of the remains. Even though DNA matches had been expedited, it was clear that preparations for a second round of tests hadn't been made and families were expecting the bodies to be repatriated without any additional delay. It appears that some families went ahead and exhumed numbered remains based on the ICMP matches and those that remained at the site were assigned a name to the number on the grave. ${ }^{114}$

What happened with the matches that were made regarding the DNA samples from the Bin Jawad case is indicative of a communications problem between what was going on in the field and the ICMP DNA laboratory. In the end, as predicted by the author at the time, there was no reliable chain of custody between the field and the ICMP laboratory that conducted the DNA analysis and matching. These problems arose from the disregarding, primarily by MAFMM, of existing national capacity, resources, and the necessary judicial framework.

Unlike many of the Latin American countries, where families distrusted their governments for good reasons, Libyans were emerging from the conflict in the hopes of that their new government would be transparent and treat everyone equally. Nor were there no capacity and resources at all in Libya, as was the case in the post-Yugoslav context. In Libya, the arguments for short term goals of expediting human identifications to satisfy victims' families demands came at expense of an inclusive, independent, transparent and credible process driven and owned by Libyan institutions themselves who were willing and capable at high levels to do so.

The Libyan case of Bin Jawad is an example of where the argument of expediting DNA assisted human identifications resulted in countering the possibility for an integrated solution within the country's transitional justice context where accountability needed to be addressed as part of a political solution. In a very real sense the MAFMM's bias towards the martyrs in the conflict led to ignoring national jurisdictional stakeholders which should have had a controlling role in any DNA assisted human identifications.

\section{Conclusion}

The emergence of human identification methods based on the comparison of DNA profiles has had a significant impact upon human identification efforts, which, prior to the advent of DNA technology, relied on traditional methods such as body landmark comparisons. States experiencing or emerging from armed conflict face a myriad of challenges, among them, how to find, identify and repatriate the dead. DNA is an important tool in human identification efforts involving large numbers of unidentified victims, but many states facing such an effort lack the necessary forensic infrastructure, capacity or legal framework.

The DNA laboratory has come to dominate many aspects of human identification efforts as information management needs to be centralized around biological sample collection, DNA laboratory extraction, and DNA database analysis through the use of specialized databases and software. The DNA profile only gains importance when it is entered into and analysed by a database and its software. Key to the overall human identification effort therefore is not so much who runs the laboratory that extracts the genetic profiles, but who owns the means to generate DNA matches.

\footnotetext{
${ }^{112}$ International Commission on Missing Persons, "ICMP Submits 95 New DNA Match Reports to Libyan Authorities to Expedite Identification Efforts," March 16, 2013, accessed March 21, 2017, http://www.icmp.int/press-releases/icmpsubmits-new-dna-match-reports-to-libya/.

${ }^{113}$ Personal communication with MAFMM staff, March 2013.

${ }^{114}$ Personal communication with former MAFMM staff, 2016.
} 
Laboratory work can be outsourced, provided there are clear agreements defining exactly what type of DNA extraction is used, the purposes for which it is to be used, the circumstances in which it can be shared, and a clear framework for jurisdictional oversight and review.

The string of numbers that represent unique DNA profiles for human identification purposes in and of themselves do not relay any personal information, and at present do not contain any information other than the gender of the individual. The DNA profile only gains significance when it is compared via specialized software to other profiles in a database and then can only identify biological relationships between individuals, leading to the actual identification of the remains. This can lead to the discovery of previously unknown or unreported sensitive biological relationshipsand the social and legal issues that this may entail-but can not shed any light on the ethnic, religious, or political affiliations of specific individuals or groups. In contrast, the biological sample can be used to extract a wealth of personal genetic information beyond that required for generating the DNA profile. This though is done using entirely different laboratory procedures than those applied in the extraction of a DNA profile for human identification purposes.

Key to any success in generating DNA matches, which then lead to positive identifications, are chain of custody level standards at all stages of the human identification effort, from collecting samples and antemortem data in the field to coordination with the DNA database effort and official acknowledgement of the death. The antemortem data and biological samples are collected in the field and can not be effectively separated or outsourced to a DNA database and its analytical capabilities as they are subject to national legislation and judicial responsibilities. As the Libyan example highlights - where not only the DNA profile extraction but also the DNA analysis and matching were outsourced-the argument for expediency in the case of Bin Jawad lead to uncertainties in the identification process and the repatriation of remains.

The authors maintain that human identification efforts in states experiencing and emerging from armed conflicts need to be owned by national actors within that state's jurisdiction. Human identification efforts cannot be separated from the need for an integrated solution within a transitional justice context in which accountability and the right to the truth are addressed as part of a political solution. The legitimacy and effectiveness of human identification efforts in transitional contexts depends on local engagement, knowledge, capacity and legal frameworks. Success should not be measured by number of DNA matches alone. Equally important is enabling national stakeholders with the needed scientific means-DNA database and its analytical capabilities-rather than separating them from it. Attempts to minimize delays at the expense of building local knowledge and skills, as well as developing the necessary legal frameworks, may risk undermining the legitimacy of the human identification effort. Whilst outsourcing DNA matching has undoubtedly led to positive identifications in some cases where they otherwise might not have occurred, in the absence of local ownership and enabling, it is likely to increase the myriad of political, legal, and social challenges faced by states experiencing or emerging from armed conflict.

\section{Bibliography}

Baraybar, Jose Pablo, Valerie Brasey, and Andrew Zadel. "The Need for a Centralised and Humanitarian-based Approach to Missing Persons in Iraq: An Example from Kosovo." The International Journal of Human Rights 11, no. 3 (2007): 265-274. https://doi. org/10.1080/13642980701443335

Beran, Roy. "The role of the expert witness in the adversarial legal system." Journal of Law and Medicine 17, no. 1 (2009): 133-137.

Budowle, Bruce and Angela Van Daal. "Forensically relevant SNP classes." BioTechniques 44, no. 5 (2008): 603-610. https://doi.org/10.2144/000112806

Budowle, Bruce, Frederick R. Bieber and Arthur J. Eisenberg. "Forensic aspects of mass disasters: Strategic considerations for DNA-based human identification." Legal Medicine 7 (2005): 230-243. https://doi.org/10.1016/j.legalmed.2005.01.001

Convention on the Rights of the Child. Opened for signature 20 November 1989, 1577 U.N.T.S. 3, entered into force 2 September 1990.

Dolinak, David and Evan Matshes. "Identification." In Forensic Pathology: Principles and Practice, edited by David Dolinak, Evan Matshes and Emma O. Lew, 555-562. Burlington: Elsevier, 2005. 
Freckelton, Ian. "DNA Profiling: Forensic Science under the Microscope." Criminal Law Journal 14, no. 1 (1990): 23-41.

Galella, Patricio. "Privatising the search and identification of human remains: the case of Spain." Human Remains and Violence 1, no. 1 (2015): 57-74. https://doi.org/10.7227/HRV.1.1.5=

Geneva Convention for the Amelioration of the Condition of the Wounded and Sick in Armies in the Field. Opened for signature 27 July 1929, 118 LNTS 303, entered into force 19 June 1931.

Geneva Convention for the Amelioration of the Condition of the Wounded and Sick in Armed Forces in the Field. Opened for signature 12 August 1949, 75 UNTS 31, entered into force 21 October 1950.

Geneva Convention for the Amelioration of the Condition of Wounded, Sick and Shipwrecked Members of Armed Forces at Sea. Opened for signature 12 August 1949, 75 UNTS 85, entered into force 21 October 1950.

Geneva Convention relative to the Treatment of Prisoners of War. Opened for signature 12 August 1949, 75 UNTS 135, entered into force 21 October 1950.

Geneva Convention relative to the Protection of Civilian Persons in Time of War. Opened for signature 12 August 1949, 75 UNTS 287, entered into force 21 October 1950.

Innocence Project. 2016. Accessed April 27, 2017. https://www.innocenceproject.org/.

International Commission on Missing Persons. "Data Protection." 2017. Accessed March 20, 2017. http://www.icmp.int/the-missing/approaches-and-standards/data-protection/.

-------. "DNA Genetic testing and processing information sheet." February 3, 2016. Accessed March 21, 2017. http://www.interno.gov.it/sites/default/files/allegati/icmp st ls 2994 doc-scheda dna.pdf.

------. “Bosnia and Herzegovina." June 18, 2014. Accessed March 21, 2017. https://www.icmp.int/ where-we-work/europe/western-balkans/bosnia-and-herzegovina/.

"ICMP Submits 95 New DNA Match Reports to Libyan Authorities to Expedite Identification Efforts." March 16, 2013. Accessed March 21, 2017. http://www.icmp.int/press-releases/ icmp-submits-new-dna-match-reports-to-libya/.

-------. “DNA Reports Guide." December 16, 2010. Accessed March 21, 2017. https://www.icmp.int/ wp-content/uploads/2015/04/icmp-fsd-dna-50-2-doc.pdf.

-------. “Agreement between the International Commission on Missing Persons and the Government of the Republic of Croatia regarding the status of the International Commission on Missing Persons office in the Republic of Croatia." September 3, 2002. Accessed March 21, 2017. http://www.icmp.int/wp-content/uploads/2014/08/agreement-icmp-roc.pdf.

. "Headquarters Agreement between the International Commission on Missing Persons and the Council of Ministers of Bosnia and Herzegovina," April 26, 1998. Accessed March 21, 2017. http://www.icmp.int/wp-content/uploads/2014/08/hq-agreement-with-bih-mofa.pdf.

International Committee of the Red Cross. Missing People, DNA Analysis and Identification of Human Remains: A guide to best practice in armed conflicts and other situations of armed violence, 2 nd ed. Geneva: ICRC, 2009.

-------. Customary International Law (ICRC, 2017). Accessed March 20, 2017. https://ihl-databases. icrc.org/customary-ihl/eng/docs/home.

International Convention for the Protection of All Persons From Enforced Disappearance. Opened for signature 6 February 2007, 2716 U.N.T.S. 3, entered into force 23 December 2010.

International Covenant on Civil and Political Rights Arts. Opened for signature 19 December 1966, 999 U.N.T.S. 171, entered into force 23 March 1976.

Interpol. Disaster Victim Identification Guide, Interpol, 2014. Accessed March 21, 2017. https://www. interpol.int/INTERPOL-expertise/Forensics/DVI-Pages/DVI-guide.

------. Interpol Tsunami Evaluation Working Group: The DVI Response to the South East Asian Tsunami between December 2004 and February 2006. Interpol, 2010.

Jugo, Admir and Senem Skulj. "Ghosts of the past: The competing agendas of forensic work in identifying the missing across Bosnia and Herzegovina." Human Remains and Violence 1, no. 1 (2015): 39-56. https://doi.org/10.7227/HRV.1.1.4

Kirby, Michael. "Forensic Evidence: Instrument of Truth or Potential for Miscarriage?" Journal of Law, Information and Science 20, no. 1 (2010): 1-20. 
MacKinnon, Gaille and Amy Z. Mundorff. "The World Trade Center-September 11, 2001." In Forensic Human Identification: An Introduction, edited by Timothy James Upton Thompson and Sue M. Black, 485-499. Boca Raton: CRC Press, 2007.

Mnookin, Jennifer L. "People v Castro: Challenging the Forensic Use of DNA Evidence." Journal of Scholarly Perspectives 3, no. 1 (2007): 77-105.

National Institute of Justice. Lessons Learned From 9/11: DNA Identification in Mass Fatality Incidents. Washington DC: National Institute of Justice, 2006.

-------. Mass Fatality Incidents: A Guide for Human Forensic Identification. Washington, DC: National Institute of Justice, 2005.

Neier, Aryeh. War Crimes: Brutality, Genocide, Terror, and the Struggle for Justice. New York: Random House, 1998.Office of the High Commissioner for Human Rights (OHCHR).

Promotion and Protection of Human Rights: Study on the Right to the Truth, UN Doc E/CN.4/2006/91, 8 February 2006.

Orentlicher, Diane. Report of the independent expert to update the Set of Principles to combat impunity, Addendum, "Updated set of principles for the protection and promotion of human rights through action to combat impunity," UN Doc E/CN.4/2005/102/Add.1, 8 February 2005.

Parven, Khaleda. "Forensic Use of DNA Information v Human Rights and Privacy Challenges." University of Western Sydney Law Review 17 (2013): 41-65.

Protocol Additional to the Geneva Conventions of 12 August 1949, and relating to the Protection of Victims of International Armed Conflicts. Opened for signature 8 June 1977, 1125 UNTS 3 , entered into force 7 December 1978.

Protocol Additional to the Geneva Conventions of 12 August 1949, and relating to the Protection of Victims of Non-International Armed Conflicts. Opened for signature 8 June 1977, 1125 UNTS 609, entered into force 7 December 1978.

Sarkin, Jeremy, Lara Nettelfield, Max Matthews, Renee Kosalka. Bosnia and Herzegovina, Missing Persons from the Armed Conflicts of the 1990s: A Stocktaking. Sarajevo: International Commission on Missing Persons, 2014.

Schmitt, Stefan, Amanda Sozer, Gillian Fowler and Dallas Mazoori. "Physicians for human rights: the role of forensic archaeology in transitional justice contexts." In Forensic Archaeology: A Global Perspective, edited by W.J. Mike Groen, Nicholas Márquez-Grant and Rob Janaway, 471-478. Chichester: Wiley-Blackwell, 2015. https://doi.org/10.1002/9781118745977.ch53

Schmitt, Stefan, Amanda Sozer, William Haglund, Nizam Peerwani, Howard Varney and Robert Lamburne. Libyan Human Identification Needs Assessment and Gap Analysis. Cambridge: Physicians for Human Rights, 2013.

Schmitt, Stefan, Amanda Sozer and Dallas Mazoori. Securing Afghanistan's Past: Human Identification Needs Assessment and Gap Analysis. Cambridge: Physicians for Human Rights, 2013.

Segen's Medical Dictionary. "Positive identification." Accessed August 5, 2016. http://medicaldictionary.thefreedictionary.com/positive+identification.

Sozer, Amanda. DNA Analysis for Missing Person Identification in Mass Fatalities. Boca Raton: CRC Press, 2014. https://doi.org/10.1201/b16475

Sozer, Amanda, Michael Baird, Michelle Beckwith, Brian Harmon, Demris Lee, George Riley and Stefan Schmitt. Guidelines for Mass Fatality DNA Identification Operations. Bethesda: AABB, 2010.

United Nations. Statute of the International Criminal Tribunal for the former Yugoslavia, May 25, 1993. UN Doc S/RES/827.

-------. Final Report of the Commission of Experts Established Pursuant to Security Council 780, May 27, 1994. UN Doc. S/1994/674.

-------. Draft Code of Crimes against the Peace and Security of Mankind with Commentaries in Report of the International Law Commission on the work of its forty-eighth session 6 May - 26 July 1996, UN Doc A/51/10.

Universal Declaration of Human Rights. G.A. Res. 217A (III), UN GAOR, 3rd session, 183rd plen mtg., UN Doc A/810, 10 December 1948.

Vollen, Laurie. "All That Remains: Identifying the Victims of the Srebrenica Massacre." Cambridge Quarterly of Healthcare Ethics 10, no. 3 (2001): 336-340. https://doi.org/10.1017/ $\underline{\text { S0963180101003140 }}$ 
Williams, Robin and Paul Johnson. "Inclusiveness, effectiveness and intrusiveness: Issues in the developing uses of DNA profiling in support of criminal investigations." Journal of Law, Medicine and Ethics 33, no. 3 (2005): 545-558. https://doi.org/10.1111/j.1748-720X.2005. $\underline{\mathrm{tb} 00517 . x}$ 